\title{
Sida Košutić's Christian Mysticism - on the Periphery of the Canon of National Literature
}

Summary: The research shows several key causes of the reception and literary-historical periphery of the rich literary oeuvre of the Croatian poet, essayist, storyteller and author of one drama, Sida Košutić. While much of the research to date has cited the ideological and world-view causes of Sida Košutić's marginal position in the canon of national literature, the writer's expression of the unspeakable at the key of the Christian mystical experience is predominantly explored here. Thus, this research fits in with the contemporary interest in the philosophy of language and literary theory in the problem of the expression of the unspeakable (L. Wittgenstein, K. Jaspers, J. Derrida, M. Sells, etc.). The prominent elements of mystical discourse in the writer's lyrical expression are analyzed on the example of a poem ("Ime tvoje sveti se") which brings the majoritiy of poetic techniques from the entire collection Vjerenička žetva. Mystical hermeticism is also one of the possible causes of the peripheral status of Sida Košutić's work. However, if the interpretation includes postmodern approach to language, it can be concluded that the poetic expression goes beyond the semantic atomism (the unspeakable refers to different experiences, conditions and realities), opposing representationalism and referentialism language model. Sida Košutić's critical subject finds its legitimacy in Christian mysticism. The work of this writer can be equally included in the poetic guidelines of Croatian modern literature of the first half of the 20th century, thus undermining the dominant notions of the center and periphery defined by the national literary canon.

Keywords: Sida Košutić, Christian mysticism, unspeakable, periphery, Croatian modern literature 


\section{The Literary-Historical and Social Context of Sida Košutić's Placement on the Periphery}

Although she was read before WWII, and highly regarded by the eminent literary critics of the time (Ljubomir Maraković, Ton Smerdel et al.), published in periodicals and anthologies, translated into world languages and awarded, the Croatian poetess, essayist, short story writer and author of one drama Sida Košutić (1902-1965), after 1945 (with several exceptions) experienced an increasingly shallow reception in literary criticism, and found her work ignored and unheard in contemporary overviews of the history of Croatian literature. While, for example, Slavko Ježić placed Sida Košutić beside Štefa Jurkić, among the younger generation of female writers oriented toward Catholicism, and among the writers in the circle of the so-called Catholic Modernism, ${ }^{1}$, Antun Barac (Jugoslavenska književnost, 1959) and Ivo Frangeš (neither in the first edition in 1978, nor in the second, enlarged edition in 1987) do not even mention her. The writer Sida Košutić was herself aware that Catholicism could have been a possible ideological argument for the placement of her work on the periphery, but also as a form or tendency that could negatively affect the aesthetic quality of the text: this was the reason why, in articles and interviews, she resolutely refused to be placed in any ideological frame. What is at hand here is her article "On Art", which she had written as an addendum to a questionnaire on Catholic literature in 1935. Seeing that "in the very idea of art divine qualities are contained, and these cannot be active, without being constructive," ${ }^{2}$ this is what follows:

"The aim of a work of art is missed should tendency appear, and tendency appears when art falters [...] Tendency, as we have seen, is no guarantee that a work is artistically succesful. Does this mean that a work of art is without tendency? By no means. Yet it is immanent here, it undergoes a birth, at the same time as truth: with suffering in its heart and new knowledge of the spirit. [...] It is not only unecessary, but also harmful, to impose a tendency on this immanent tendency. [...] It is for this reason that I will not say that a Catholic literature exists, as literature, but that only writers exist who are Catholics"3.

\footnotetext{
${ }^{1}$ Slavko Ježić, Hrvatska književnost (Zagreb: Grafički zavod Hrvatske, reprint of the first edition of A. Velzek Publishing Office from 1944, 1993), 385.

2 Sida Košutić, "O umjetnosti (prigodom ankete o katol. književnosti)," Hrvatska prosvjeta, vol. 22, no. 10 (1935): 281-282.

${ }^{3}$ Košutić, "O umjetnosti," 281.
} 
In the $21^{\text {st }}$ century, her work has been registered in all the more important overviews of the history of Croatian literature. When elaborating on the work of Sida Košutić within the newly formed stylistic paradigm of Croatian poetry from 1930 to 1950, Cvjetko Milanja claims, on the one hand, that her poetic ideas can be understood as belonging to the realm of mysticism, almost in the sense in which this was realised in the literary works of St. Teresa, which found its source in a Catholic fascination. Yet, on the other hand, the demands of the mundane and the diurnal forced certain practical situations on her, which certainly had not only absolved what was in concordance with an idealised image of life, but must also have contradicted it (the motif of beating and punishing women $)^{4}$. She is presented as a poet possessing the "subtle and guarded sentiment of an introverted subjectivity, which, in its meditations, in the direction of transcendence, finds the meaning of its song, but also of life"s.

The themes of human existence and the individual subject, as well as the theme of the divine mystery (the incarnation of the Logos, followed by Christ's physical suffering, death and resurrection) are expressed in the works of Sida Košutić as the literalisation of reality. Because of this, the occasionally naturalistic representations of the fate of women, children and the socially impoverished generally in the first decades of the $20^{\text {th }}$ century in Croatia (especially in the Hrvatsko Zagorje region) are connected to a specifically authorial and individualised Christian symbolism and tropology; they are also intertwined with a hermetic poetic discourse with a mystical overtone, independent of genre (poems in prose and verse, the allegorical tale "Vrijeska" ("The Heather"), the dramatic work $K$ svitanju (Toward the Dawn), the volume of short stories Mimoza sa smetljišta (The Mimosa from the Garbage Dump), the trilogy of social novels $S$ naših njiva (From Our Pastures), the posthumously published modernist novel Velika šutnja (The Great Silence) etc.). Furthermore, as Stjepan Lice noted, according to Sida Košutić, if literary creation were to possess its full meaning, it must connect and harmonise creative inspiration, religious conviction and social action: "Discord between these would have the meaning of legitimacy for her".

The context of the period in Croatian literature in which Sida Košutić wrote is one in which a generation of writers in the 1920s and

\footnotetext{
${ }^{4}$ Cvjetko Milanja, Hrvatsko pjesništvo 1930.-1950. Novostvarnosna stilska paradigma (Zagreb: Matica hrvatska, 2017), 165.

${ }^{5}$ Milanja, Hrvatsko pjesništvo, 167.

${ }^{6}$ Stjepan Lice, "Sida Košutić: književnost svjetlosti," Kroatologija, vol. 6, no. 1-2: 325.
} 
1930s appeared ${ }^{7}$. The first phase of this period is understood as the time of avant-garde experiments and explorations of the possibilities of literary expressionism, while the second phase is characterised by the entrance of social topics within synthetic realism (1921-1941) or modern objectivism $^{8}$. The works of the Catholic literary project ${ }^{9}$ as well as the period which saw an expansion of texts written by women writers in the first decades of the $20^{\text {th }}$ century, provide an important context for her literary work. Meanwhile, what we are dealing with here, in a literary and aesthetic sense, is a specifically heterogeneous period of various idiosyncratic poetics and strong personalities such as: Miroslav Krleža, Antun Branko Šimić, Tin Ujević, Slavko Kolar, Vjekoslav Majer, Đuro Sudeta, Nikola Šop, Dobriša Cesarić, and Dragutin Tadijanović, who had dominated the literary scene of their time, thus obscuring many contemporaries, Sida Košutić among them. Lidija Dujić (2002) took special note of this ${ }^{10}$. Yet Nada Šimunić-Kesterčanek, in her introduction to the volume of prose Mimoza sa smetljišta, places Sida Košutić beside Ivana Brlić-Mažuranić, Jagoda Truhelka, Mila Miholjević, Mara Švel, Božena Begović, and Dora Pfanova ${ }^{11}$, emphasising here and

\footnotetext{
${ }^{7}$ An insight into her collected bibliography shows us that she began with (lyrical) essays in the periodical Novi čovjek 1926. This was followed by the drama K svitanju (Toward the Dawn) 1927. Then she published her first novel Portreti (Portraits) in 1928, two poems and one sketch in the periodical Hrvatska prosvjeta, where she published permanently in the following years. Her literary retelling of a hagiography Sluga vječne Mudrosti (The Servant of Eternal Wisdom) was published in 1930, and in the same year she published several of her poems in the periodical Za vjeru i dom. Her novel Jaslice (The Nativity) was published in 1933, as well as some shorter prose and poetry in Hrvatska prosvjeta and the magazine Obitelj. The first part of her prose trilogy $S$ naših njiva (Plodovi zemlje) Roman iz seljačkog života (From Our Pastures (The Fruits of the Earth) A Novel of Rural Life) was published in $1935 / 6$, and the same years saw her continued literary collaboration with these aforementioned periodicals. She published one more essay in literary criticism in 1937, titled "Na putu umjetnosti" ("On the Path to Art") in Hrvatski dnevnik, and in the same year the second part of her trilogy S naših njiva (Magle) (From Our Pastures (Fog), as well as certain poems in various periodicals. In 1938 she primarily published poetry in many periodicals, including Hrvatska straža.

${ }^{8}$ Miroslav Šicel, Povijest hrvatske književnosti XX. stoljeća. Razdoblje sintetičkog realizma : (1928-1941), knj. 5 (Zagreb: Naklada Ljevak, 2009), 8.

${ }^{9}$ Compare: Vladimir Lončarević, Književnost i hrvatski katolički pokret (1900.-1945.) (Zagreb: Alfa, 2005).

${ }^{10}$ Lidija Dujić, "Ženska signatura. U povodu stote godišnjice rođenja Side Košutić," Vijenac, no. 229 (2002), accessed July 18, 2020, http://www.matica.hr/vijenac/229/zenskasignatura-13332/.

${ }^{11}$ Nada Šimunić-Kesterčanek, "Sida Košutić kao umjetnica," Introduction to: Sida Košutić, Mimoza sa smetliišta (novele) (Zagreb: Be-1-ka, 1942), 7.
} 
arguing that women writers (just as male writers) create the national literary canon. Furthermore, we find the second cause for Sida Košutić's placement on the periphery in the long silence and underestimation of women writers in the first half of the $20^{\text {th }}$ century who had professionally organised themselves for the first time (they founded the Society of Croatian Women Authors in 1936, in which Sida Košutić also participated), established literary periodicals, and included topics of the so-called women's writing (the engaged and literary form of the real experience of being a woman in a patriarchal society). The third reason why Sida Košutić's work has been placed on the periphery is that she wrote during the period of the NDH (Nezavisna Država Hrvatska / The Independent State of Croatia), so that after the war Sida Košutić's work suffered "a neglect of reception of almost half a century"12.

And yet, an evidence that Sida Košutić's relationship with the Ustaša regime was far from idyllic (despite receiving literary awards) was that her name was not even mentioned in an unsigned text titled "Ženski sat na krugovalu" ("Woman's Hour on the Radio"), published in the very Hrvatski ženski list (1943, no. 7-8, pg. 23), the journal she was editing, among the writers of the cycle of this Croatian author. After WWII, the fact that she was the editor of the aforementioned journal proved to be her greatest burden.

Yet, even within the Catholic literary and cultural circles in Croatia, not everyone eagerly awaited Sida Košutić's writing. Even Ljubomir Maraković himself, in his analysis of her work Portreti (Portraits), notes that there are passages which would not be to the liking of clerical critics: "Some might be bothered that Romana calls mother God, although she uses other expressions besides this. Yet one should take into consideration, that mysticism is in fact the personal relationship between the spirit toward God, and that even the most orthodox Christian mystics struggle to find an adequate expression for their individual sense of God's love"13. This quote from Maraković confirms the legitimacy of the initial thesis of our research - that the mystical discourse in its obliqueness, sometimes in its subversiveness (and this is something which can certainly be found in Sida Košutić's works) is also one of the possible reasons that have led to the multifaceted placement of her work on the periphery.

\footnotetext{
${ }_{12}$ Dunja Detoni Dujmić, Ljepša polovica književnosti (Zagreb: Matica hrvatska, 1998), 335.

${ }^{13}$ Ljubomir Maraković, Novi pripovjedači, kritičke studije i minijature (Zagreb: Hrvatsko društvo sv. Jeronima, 1929), 126.
} 


\section{Placement on the Periphery and Mystical Discourse in Literature}

What will follow in our paper is an analysis of the elements of Christian mysticism which Sida Košutić used in order to construct her poetics in her drama $K$ svitanju (Toward the Dawn), to her last (posthumous) work, the novel Velika šutnja (The Great Silence). It is certain that not all of her works will be presented here. The subject of her body of work will be confined here to the text of her poem "Ime tvoje sveti se" ("Thy name be hallowed") from her volume Vjerenička žetva, and we will show its contextual relationship with our analysis of her drama $K$ svitanju $^{14}$, in which she had already shown an inclination toward mystical hermetism, as it has been characterised by Vladimir Lončarević ${ }^{15}$ and by Božidar Petrač ${ }^{16}$. We will base our analysis of mystical hermetism on the work on the expression of the unsayable in the philosophy of language and literary theory (Ludwig Witgenstein, Karl Jaspers, Jacques Derrida, Michael Sells), as the unsayable represents an essential characteristic of the mystical discourse and the language of mystics is often a source for researchers. In our analysis we will also include some of the determinants of motifs and theme which Milan Špehar deduced as constitutive in the tradition of Christian mysticism.

According to Richard Rorty, who edited a collection of papers from 1967 and popularised the term "the linguistic turn" in his introduction to this book, without a valid understanding of language there can be no development of any other philosophic discipline: thus the philosophy of language becomes a central field of philosophy ${ }^{17}$. Without this aforementioned understanding of language it is impossible to delve more deeply into the layers of modern poetry which are founded on the path of mystical hermetism so that such bodies of work may remain on the periphery due to their impenetrability. A better understanding of Sida Košutić's language is a condition for the better reception of her

\footnotetext{
${ }^{14}$ Compare: Kornelija Kuvač-Levačić, "Intertekstualnost drame K svitanju Side Košutić i Pjesma nad pjesmama kao prototekst," Crkva u svijetu, vol. 54, no. 1 (2019): 17-41.

${ }^{15}$ Lončarević, Književnost i hrvatski katolički pokret, 305.

${ }^{16}$ Compare: Božidar Petrač, "Mistički hermetizam Side Košutić (1902. - 1965.). Uz 50. obljetnicu pjesnikinjine smrti," Zadarska smotra, vol. 64, no. 3 (2015): 35-39.

${ }^{17}$ Matko Sorić, "Semantički holizam i dekonstrukcija referencijalnosti: Derrida u analitičkom kontekstu," Prolegomena : Časopis za filozofiju, vol. 10, no. 2 (2011): 284, accessed October 7, 2019, https://hrcak.srce.hr/74467.
} 
work, not only of her poetry but also prose, especially in those portions which are realised through the aesthetic procedures of mystical hermetism.

The position of the critical subject in the lyric discourse will be taken into consideration, and we will attempt to expand our knowledge on the additional causes why this poet has been placed on the periphery, causes which are not exclusively due to social or political circumstances, yet are hidden within the subversive potential of the mystical discourse itself. This discourse is constructed on the personal experience of a lived Christian spirituality, and the embodiment of this experience in a literary work is what greatly informs the individual poetics of this author. Her work can be viewed in the context of the typology of the Croatian poets of the 1930s and 1940s, as described by Pavao Pavličić, belonging to that group of poets whose world-view had become "a source of poetic inspiration in a way that it is made problematic, so that it, thus, is translated from the level of the primary and the doctrinaire into the language of images and thus transformed and expanded" 18 . The characteristics of the mystical discourse in the construction of this author's poetics show Sida Košutić's integration in the context of the poets of the 1930s and 1940s, as among them, Nikola Šop (for example) also places great emphasis on an understanding of the divine in the mundane life of men, also portraying the mystical unity between God and man ${ }^{19}$. The mystical discourse can also be considered as part of the poetic strategy with which the principles of doctrine are given new meanings, brought into a new context and thus gain a new meaning ${ }^{20}$. And yet this becomes a reflexion or conveyer of the subversive potential of this author's poetic strategies as these also possess content which can be read as a critique of materialism and the subjection of women (in her drama $K$ svitanju and in large segments of her narrative prose), superficial religious devotion in her novels Sluga vječne mudrosti, Jaslice, Velika šutnja et al., and the social practices which abuse the Bible with the aim to subjugate the vulnerable, especially women and children (her trilogy $S$ naših njiva for example), but also in her general critical atti-

\footnotetext{
${ }^{18}$ Pavao Pavličić, "Hrvatska lirika tridesetih godina: tipološki opis" in Komparativna povijest hrvatske književnosti - Zbornik radova VII. (Hrvatska književnost tridesetih godina dvadesetog stoljeća), eds. Cvijeta Pavlović and Vinka Glunčić-Bužančić (Split: Književni krug, 2005), 40.

${ }^{19}$ Cvjetko Milanja, Hrvatsko pjesništvo 1900.-1950. Novosimbolizam. Dijalektalno pjesništvo (Zagreb: Jerkić tiskara, 2008), 254.

${ }_{20}$ Pavličić, "Hrvatska lirika tridesetih godina: tipološki opis," 40.
} 
tude toward the ethical relativism of the modern world (Portreti, Velika šutnja). Furthermore, it is a known fact that throughout human history mystics were often considered a danger to the state and the church as:

"[...] it is with difficulty that communities accept the solitary seeking and paths on the edge of the mundane consciousness. Mystics never appear before the world as people who console. They are often subject to ridicule during the course of their lives, humiliated and forced to remain silent. After their deaths they are offered as examples by the semi-faithful" ${ }^{\prime 21}$.

Although the author's critical engagement will not entirely embody the mystical discourse as the dominant strategy of expression in all the texts we will cite in this work, we will cite them here in order to provide the context for those texts (primarily her drama and lyric) in which this form of discourse is dominant.

\section{The Amplitude of Mysticism and Realism in Sida Košutić's Texts}

Without an understanding of Christian mysticism in the semanticsymbolic layer of the motif of sacrifice ${ }^{22}$, which had been inscribed in the texts that belong to her (for want of a better term) realistic phase, it seemed to some of those who interpreted Sida's literary engagement, that she remained either inadequately critical or overly mild when compared to the socially engaged texts of her female contemporaries ${ }^{23}$. And yet a close reading of her works shows that this writer was definitely engaged and critical, and certainly did not have her eyes closed upon social malaise, the horrors of war (e.g. her poems "Kraljevstvo Satane" ("The

\footnotetext{
${ }^{21}$ Marie-Madeleine Davy, "Predgovor," in Enciklopedija mistika, 1st vol., ed. M. Davy (Zagreb: Naprijed, 1990), 8.

${ }^{22}$ The key discursive connection with the oxymoronic structure of Meister Eckhart's thought: "[...] the highest heights of exaltation lie precisely in the lowest depths of humiliation; for the deeper the valleys go, the loftier the heights that rise above them; the deeper the well, the higher too: for depth and height are the same thing. Therefore the more humble a man may be, the more exalted he will be" (Raymond B. Blakney, Meister Eckhart, A Modern Translation (New York, Hagerstown, San Francisco, London: Harper Torchbooks, 1941), 37).

${ }^{23}$ Milanja, Hrvatsko pjesništvo 1930.-1950. Novostvarnosna stilska paradigma, 166.
} 
Kingdom of Satan") and "Hvala neprijatelju" ("Thank You Enemy") from Vjerenička žetva), and the post-war exile (the cycle of poems "Noć domovine" ("Night of the Homeland") in her volume Jezero mrtvo (The Dead Lake). Even in her very first pages, her theme was the inequality and abuse of women, which she would later develop into themes which included themes of forced prostitution and she constructed the character of the pimp, who is the owner of the factory in Velika šutnja. She also elaborated the theme of the self-loving politician and intellectual as well as the disenfranchisement of the poor (e.g. in her volume of short stories Mimoza sa smetljišta, her novel Jaslice, in the trilogy $S$ naših njiva, in drama, poems, lyrical essays etc.). By inscribing traumatic social and psycho-physical experiences in the constructs of her primary female protagonists, she demarcated a very real background with which she informed the theme of the Christian mystery of the sacrifice, thus, the mysticism of the passion as the way toward the "light", i.e. toward spiritual redemption, a personal encounter with God, but also as an "an existential and personal speech about Jesus's sacrifice which attempts to make the event of the Cross existentially comprehensible in the circumstances of a new cultural paradigm," which Veronika Nela Gašpar mentioned as the theological concept of martyrdom for modern day Christianity ${ }^{24}$.

The semantic and symbolic layer of expression in Sida Košutić's poetics is emphatically connected to Christian symbolism and its sources in the Bible and the liturgy, yet generally with the linguistic practices and strategies of expression which have been recognised as universally characteristic of the mystical discourse. Even as in cases when a poem's auditory structure begins to overpower its content, the utilisation of the strategy of the mystical discourse can be interpreted as a reflection of the poet's "doubts in language and its ability to convey something essential" 25 . "Practical" position of words and language generally refers to the mere appearance of the world, yet poetry contravenes such representationalism and referentiality. Contravening such has become the theoretical core of the post-modern linguistic model.

\footnotetext{
${ }^{24}$ Veronika Nela Gašpar, "Teološko poimanje mučeništva," in Mučeništvo i mučenički tragovi kroz hrvatsku prošlost. Zbornik radova s međunarodnog znanstvenog skupa održanog u Zagrebu 13. ožujka 2014. godine, ed. Mile Bogović (Zagreb: Glas Koncila, 2015), 43.

${ }^{25}$ Pavličić, "Hrvatska lirika tridesetih godina: tipološki opis," 44.
} 


\section{Mystical Discourse and the Utterance of the Unsayable - the Overcoming of Representationalism and Referentialism in Language}

One of the dimensions of knowledge is earthly, empirical and knowable, while the other is non-empirical, unknowable, which lies on the other side of "this" world and it is this dimension of knowledge which Karl Jaspers terms transcendence, the all-encompassing, true Being, divinity etc., while the early Ludwig Wittgenstein, in this sense, speaks of the dimension of the mystical ${ }^{26}$. This consciousness brought both philosophers to the point of silence where questions concerning the unsayable were concerned ${ }^{27}$, yet it is a fact that there were attempts to overcome the paradox of the "utterance of the unsayable" in different ways and through various textual strategies. According to A. M. Haas, in the end, the powerlessness of language is also the power of language, and an avowal of the unsayability of language is a miracle of language, a chance for language's reality ${ }^{28}$ : here the cited author gives great importance to literary language as a means of the mediation of the unsayable.

Michael A. Sells also defines the unsayable in his work Mystical Languages of Unsaying (1994), stating that it signifies a discourse in which the authentic subject constantly slips away despite the constant effort to name it and that it even denies the possibility of being named. In attempts to establish the aporia of the transcendent, it is inevitable that a regression in language occurs. Every statement - positive or negative - must be constantly corrected, refuted ${ }^{29}$. Sells links this "linguistic regression" to the Greek term apophasis, which can also mean "negation," yet its etymology suggests the meaning which more closely characterises the discourse of the unsayable ${ }^{30}$. Apophasis can reach such a degree of intensity that not a single thought, which pertains to the transcendent, can remain independent. It is in the ten-

\footnotetext{
${ }^{26}$ Ante Periša, Neizrecivo kod Jaspersa i Wittgensteina (Zadar: Hegelovo društvo, 2010), 12.

${ }^{27}$ Periša, Neizrecivo kod Jaspersa $i$ Wittgensteina, 16.

${ }^{28}$ A. M. Haas, Sermo mysticus, Freiburg Schweiz: Universitätsverlag, 1979, cit. in: Milan Špehar, "Mistika u životu kršćana," Bogoslovska smotra, vol. 75, no. 1 (2004): 107, accesed August 12, 2020, https://hrcak.srce.hr/25648.

${ }^{29}$ Michael A. Sells, Mystical languages of unsaying (Chicago: The University of Chicago Press, 1994), 2.

30 "[...] apo-phasis (un-saying or speaking-away)" (Michael Sells, Mystical languages of unsaying, 2).
} 
sion between the stated and the refuted that such discourse becomes meaningful ${ }^{31}$.

The knowledge of the mystical discourse inevitably pertains to speech/statement in Jacques Derrida's theory, which, contravening the referentiality of meaning in language and metaphysical logocentrism, analyses the inaptitude of every predicative language for the essence, hyper-essentiality (a being outside Being) of God. It is for this reason that only negative (apophatic) attributions can confirm that they have come close to God, and prepare us for a "silent intuition of God"32. Derrida connects the refuted predetermination of an unsayable reality (which he demarcates as $\mathrm{X}$ ) with the characteristics of apophatic theology, and recognises such characteristics in every statement which continually returns, infinitely multiplying its defences and apophatic warnings before the expression of this $\mathrm{X}$. Despite its appearance, $\mathrm{X}$ is neither concept nor name, is founded in a series of names, yet requires a different syntax and transgresses the order (rules) and structure of a predicative statement. This X "is not" and does not say what "is". It is transcribed in an entirely different way ${ }^{33}$.

Špehar as well, like Sells, enumerates paradox, dialectics, allegory, metaphor, oxymoron as fundamental in the expression of the unsayable in mystical discourse, stating that mystics themselves remain conscious that they may have contributed more to poetry than theology, so that it is often the case that literature "more and with greater seriousness studies them than does theology" ${ }^{34}$. The inability of utterance gives birth to the power of art.

The postmodern theory of meaning developed on the basis of such conclusions, articulated in Jacques Derrida's theory of language, which is based on a semantic holism and a critique of referential theories of meaning ${ }^{35}$. Referentialism, on the other hand, is based on the metaphysical

${ }^{31}$ Sells, Mystical languages of unsaying, 3.

32 Jacques Derrida, "How to avoid speaking: denials," in Languages of the unsayable. The play of negativity in literature and literary theory, eds. Sanford Budick, Wolfgang Iser (Stanford: Stanford University Press, 1996), 4.

${ }^{33}$ Derrida, "How to avoid speaking: denials," 4.

${ }^{34}$ A. M. Haas, Sermo mysticus, cit. in: Špehar, "Mistika u životu kršćana," 107.

${ }^{35}$ It is possible to find identical stances and similar arguments in the analytical philosophy of language, in the work of authors such as Gottlob Frege, Ludwig Wittgenstein, Austin, Searle, Quine, Davidson and Dummett. The linguistic turn in these authors results in a critique of epistemoligical realism and an advocation of epistemological antirealism and constructivism, which is subject to empirical scrutiny, primarily by an analysis of the role of metaphor in language (Matko Sorić "Semantički holizam i dekonstrukcija referencijalnosti," 281). 
presupposition of the duality between external reality and mental representation ${ }^{36}$. And yet "statements need not be either a reflection of external reality or internal intuition. And while, in principle, sentences in an indicative or declarative mode are subject to verification, those in an imperative, conditional or optative one are not" ${ }^{37}$. In his Blue Book Ludwig Wittgenstein discards the referential theory of meaning due to its reductionism ${ }^{38}$.

Here we will ask if reductionism in critical interpretations was what led to Sida Košutić's being placed on the periphery. We maintain that the methodology constructed on the principles of the postmodern theory of meaning can provide a new reading of her poetry and actualise the interpretation.

The first quality of the postmodern theory of language is to contravene representationalism, as well as referentialism, yet this does not mean that there is absolutely no connection between language and the outside world, but that its functions are not exhausted in descriptions of reality. Language is not exclusively a reflection of reality: its sentences cannot be explained as simple linguistic atoms of reference, while mental representations are not direct representations, nor are they entirely plausible duplicates of real, external objects" 39 . When elaborating the postmodern model of language through its two main postulates: semantic holism and the critique of the referential theory of language, Sorić refers to those philosophers of language who had proven that language does not consist of referential terms alone (e.g. Wittgenstein's contravention of the "Augustinianism of the philosophy of language," Derrida's contravention of logocentrism, Quine's appellation of the referential theory of language as a "myth of the museums"). Alongside this, there is also Heidegger's refutation of the existence of any mental state that could be plausibly expressed in language. It is a definite fact that neither external reality nor mental states can be entirely duplicated in language ${ }^{40}$. When mentioning the inability of language in certain passages in her essays to express existing reality, Sida Košutić shows a great awareness of the description of external reality as only one of the functions of language: thus, in the language of the philosophers, that referentialism actually ignores large domains of linguistic practice ${ }^{41}$.

\footnotetext{
${ }^{36}$ Sorić, "Semantički holizam i dekonstrukcija referencijalnosti," 288.

${ }^{37}$ Sorić, "Semantički holizam i dekonstrukcija referencijalnosti," 286.

38 Sorić, "Semantički holizam i dekonstrukcija referencijalnosti," 292.

${ }^{39}$ Sorić, "Semantički holizam i dekonstrukcija referencijalnosti," 285.

${ }^{40}$ Sorić, "Semantički holizam i dekonstrukcija referencijalnosti," 285.

${ }^{41}$ Sorić, "Semantički holizam i dekonstrukcija referencijalnosti," 289.
} 


\section{Christian Mysticism, Biblical Intertextuality and the Question of the Critical Subject}

When Derrida claims that there would be no truth without repetition, and further, that the identity of the sign depends on the possibility of its repetition, he is insisting on the intersubjective, collective and historical dimensions of language, which Wittgenstein defends with his denial of the possibility of a private language. ${ }^{42}$ In Sida Košutić's work, this historical dimension is included via biblical intertextuality and the traditions of Christian mysticism.

Milan Špehar wrote on Christian mysticism, emphasising the need to research its language and to extend the meaning of mystical phenomena and imagery. This author presents mysticism as the experience of the Not-experienced, which lives in Christianity and outside it, yet acknowledging that Christian mysticism has its basis in Holy Writ, the liturgy and the church..$^{43}$ This level of intertextualism, which receives the meaning of a spiritual dialogue in some of Sida Košutićs works with the construction of the relationship between the poetic subject and God as person, cannot be ignored when interpreting her texts. According to Derrida, every repetition of the sign occurs within a different context and modifies its meaning. Due to this impossibility of "citation," the connection between the sign and its first context are either strengthened or weakened after its repetition in another context. ${ }^{44}$

Thus, for example, the mystical discourse in the drama $K$ svitanju stands in an intertextual relationship to the Song of Songs. The characteristic metaphors of the mystical experience in the Bible are also present: light, kingdom, garden and betrothal/wedding ${ }^{45}$. Although the same motif can be sensed in both the Song of Songs and in the drama $K$ svitanju (the physical torture of its main female protagonists in both texts), this is developed in Sida Košutić's text to the level of the mystical meaning of suffering, with its images of suffering in a synecdochical fragmentation (which are dominant, yet are not the exclusive images) of the female body, she antithetically reinterprets the celebrated and beloved female body of the Song of Songs. Physical suffering leads to the establishment of the supremacy of spiritual strength as opposed to

\footnotetext{
${ }^{42}$ Sorić, "Semantički holizam i dekonstrukcija referencijalnosti," 292.

${ }^{43}$ Špehar, "Mistika u životu kršćana," 87.

${ }^{44}$ Sorić, "Semantički holizam i dekonstrukcija referencijalnosti," 294.

${ }^{45}$ Compare: Špehar, "Mistika u životu kršćana".
} 
the earlier constructed relationships of social power ${ }^{46}$ which have been established by men, the father, characterised as a character who, due to his materialism, has lost his connection with God.

In this sense, the mystic becomes a "living sign" in the world so that the mystical discourse in a literary text can enact the position of a critical subject "[...] which was the ordinary 'functionary of the symbolic order" in structuralism, and now "finds its legitimatising foundation in the 'unspoken', the 'unthought', the 'non-discursive', the 'un-representable', the 'radically other' [...] from whence it completes its critique of symbolic and imaginary reduction, and thus of linguistic 'horror' and "violence"'47. Christian mysticism becomes exactly the basis of Sida Košutić's critical subject, which we will show in our further analysis of her poem - "Ime tvoje sveti se".

\section{The Poem "Ime tvoje sveti se" (Vjerenička žetva)}

In her poem "Ime tvoje sveti se", a poem which conveys the majority of the aesthetic procedures used in her volume Vjerenička žetva, we will investigate the contravention of representationalism and referentialism in its descriptions/concepts of reality and show Sida Košutić's awareness of the functions of poetic language which are close to the functions within the mystical discourse when she makes the unsayable her theme. We will research the procedures with which this author transcended linguistic and cognitive dualism, which is also a characteristic of the mystical discourse ${ }^{48}$, which places her equally within the tendencies in the modern Croatian poetry of the 20th century. In as much as we take into account that "[...] according to Derrida, not all speakers of a certain language are the same in their relative linguistic dispositions and linguistic knowledge, and also that, consequentially, the context of meaning must always be treated as the idiolect of a concrete individual in the role of the interpreter (differrance) [...]"49, then we will comprehend the

\footnotetext{
${ }^{46}$ Kuvač-Levačić, "Intertekstualnost drame K svitanju Side Košutić i Pjesma nad pjesmama kao prototekst," 39.

${ }^{47}$ Vladimir Biti, Pojmovnik suvremene književne teorije (Zagreb: Matica hrvatska, 1997), $287-8$.

48 " [...] all great mystics have claimed that their insights transcend the dualistic structure of reason and are there fore unsayable [...]" (Sebastjan Vörös, "Mahakashyapa's Smile: Language, Silence, and Mysticism." Synthesis Philosophica, vol. 29, no. 2 (2014): 387, accessed October 18, 2019, https://hrcak.srce.hr/142433).

${ }^{49}$ Sorić, "Semantički holizam i dekonstrukcija referencijalnosti," 293.
} 
discourse of Christian mysticism in Sida Košutićs lyric expression as a context of meaning in modern Croatian poetry ${ }^{50}$ : thus as this author's idiolect in the poetic interpretation of the referent (and in instances when the referent is unsayable): without which a reading of this body of work remains lacking.

Poetry in prose or on the margins of prose and verse shows a tendency toward modernism. It enabled Sida Košutić to complete the greatest aesthetic and spiritual achievements of her expression, although it can be read in her earlier essays that she is aware of the inability of the linguistic formation of profound spiritual realities, which was also a common theme in her poetry. The inability of language to fully express profound emotional and spiritual experiences, which lead the poet to experiment with language and form, is something with which Sida Košutić is greatly preoccupied. A powerless or disabled language leans itself here on a dialogue with the Word of God, so that the expression of the unsayable within the poetic subject is created by an intertextual relationship toward the biblical proto-text. The experience of the unsayable can be announced by citation, with a verse (an explicit relationship) for example, or developed with the procedures of the thematic, semantic, symbolic or formal allusion to the proto-text (an implicit relationship). And yet, providing a semantic status to such procedures which involve citation and the entire expression, which in content and style corresponds with the mystical discourse, is not always in the function of an exclusive reinterpretation of religious content, but of a personal and life experience (the experience of being a poet for example), which is also a theme which this author shares with her contemporaries.

One of the more interesting examples for analysis of the mystical discourse in Sida Košutić's poetic utterance is certainly the poem at hand. Its very title ("Ime tvoje sveti se") is in itself the title of the Lord's Prayer, while the entire poem on the level of its utterance is constructed upon an utterance in which a female lyric and confessional subject is addressing her unborn daughter. At its inception we will note something paradoxical in the initial presentation of its referent that, in itself, has been linguistically contravened, through which the aforementioned ten-

\footnotetext{
${ }^{50}$ Taking into account the literary historical context, it is important to note that the characteristics of mystical discourse can also be found, for example, in Miroslav Krleža's early poetry (which had even then proven to be influential), especially in his poem "Duga stiha" ("Rainbow of Verse") (Zoran Kravar, Svjetonazorski separei: antimodernističke tendencije u hrvatskoj književnosti ranoga 20. stoljeća (Zagreb: Golden marketing - Tehnička knjiga, 2005, 125)).
} 
sion between the said and the unsaid, which forms the mystical meaning of the text, is enacted. The subject's lack of knowledge of itself and of the subject of utterance (a great number of negations), as well as the inability to know, are typical characteristics of apophatic mystical utterance $^{51}$. The semantic and symbolic layer of this poem is based on a series of scriptural metaphors (thirst, well, pitcher) which are indicative of a biblical proto-text, and here they conceptualise the selfhood of the poetic subject:

My unborn daughter, forgive me.

When I hurried on that fateful evening

to the well, I did not know, that you are my shadow,

that hurries after me.

When I reached for the pitcher, to drink,

I did not know, that I receive it from your hands, and that you waited a moment, to offer it to me.

When I had returned home, replenished, and after myself

locked the doors, I did not know that you were standing outside, in front of closed doors, and were waiting, for me to open them.

My unborn daughter, forgive me. ${ }^{52}$

We should note the motif of the harvest, which itself is in the title of this volume and which will appear a little later in the poem. Just as the motifs of the betrothed and betrothal, it also belongs among the scriptural metaphors of the mystical discourse. Further in the poem inside and outside spaces - house and garden are of great importance for the interpretation of mystical discourse in the same function of representation. 'House' as a the mystical symbol (we must recall Teresa of Avila's "snare of the spirit") is directly connected to the motif further in the poem (and it will also reappear in a poem of the same title a little later in this volume) and functions as a specific sign of the mystical discourse; "Mysticism roots itself in the interior: it is an interior space. There is a danger that these two worlds will be separated by a ravine due to the very masks with which human weakness conceals itself $[\ldots]^{\prime \prime 53}$.

\footnotetext{
${ }^{51}$ Compare Michael Sells, Mystical Languages of Unsaying, 3, 4.

${ }^{52}$ Sida Košutić, "Ime tvoje sveti se," in Vjerenička žetva (Zagreb: Hrvatski izdavalački bibliografski zavod, 1942), 7. (The examples in citation have been underlined by the author of this paper. Translated by Krešimir Vunić, prof.)

${ }^{53}$ Marie-Madeleine Davy, "Predgovor," 8-9.
} 
An awareness of separation and a yearning for unity is what informs the relationship between the lyric subject and the unborn daughter. The selfhood of the poetic subject is not uttered as an individual, a closed concept. The unborn daughter is its constituent part. Between the female lyric subject and the "unborn daughter" there is a motif similar to the 'ravine' as mentioned by M. M. Davy. This is a "flood" as a symbol of a manifold inability of the meeting between two "selves," despite the existence of a "ring" as a symbol of unity, integrity and eternity. 'Flood' and 'ring' show themselves to be contrasting symbols, and contrasting symbols are one of the aesthetic procedures found in Sida Košutić's poetry (butterfly and chain, prison and garden in $K$ svitanju for example). The development of a subject split between a yearning for estranged spaces, and such linguistic and symbolic relationships, as well as the aforementioned linguistic regression, refutation of prior claims and the accrual of negations are all apparent here:

My daughter, the ring is complete, it originated

in your gifts, come, so you can see it.

In vain! You could not come to me, nor I

To you, a flood rolled between us. [...]

My daughter, I return every day,

The ring is complete, come so you can see it.

In vain: we can not approach each other. $[\ldots]^{54}$

The motif of the unborn daughter is inscribed as an absolute yearning for love (the equation of daughter and love addressed in the vocative in the following example) as well as the poetic subject's awareness that this yearning will not be fulfilled for the term of its earthly life (flood, vexed wave):

Who put this vexed wave between us

And even called it life?

Why can't hands reach each other, that are

already reaching each other?

Ah, daughter, my not-to-be!

$\mathrm{Ah}$, love, that must wait, while life

is flowing and only then implores the implored. ${ }^{55}$

${ }^{54}$ Košutić, "Ime tvoje sveti se," 8.

${ }^{55}$ Košutić, "Ime tvoje sveti se," 9. 
Two mystical and symbolic spaces are formed in this poem: the interior space of the house and the exterior space of the garden - "the harvest flower bed." They converge in the third section of the poem, together with the appearance of the third person - man, father of the "unborn daughter," which at the level of its content and motif corresponds to the title of the volume of poems.

He lived alone like the wind on the height of a black mountain.

His eyes shined with the yearning of youth and extinguished

themselves in the saintly peace of an abbot.

Women would readily look into his face

And with desire would wind themselves around his body. ${ }^{56}$

Although accompanied with motifs similar to the appearance of the youth (the Gardener) in $K$ svitanju, with the garden and its subsequent symbols, what differentiates this from the procedures in the aforementioned drama, is that the metaphor of the garden does not follow its biblical archetype here. In the verses which precede these, and which have introduced the character of the youth into the content of the poem, we can recognise the connection with the phenomenological study of the spiritual values of interior space in the mystical discourse, which Gaston Bachelard ${ }^{57}$ researched, by incorporating the image of the house observed in its unity and complexity, as well as noting the pervasion of external and internal space, where "outer and inner space have [...] fallen [...] into each other" ${ }^{\prime 8}$. This is made clear in the following citation:

Only I know of our harvest flower bed, in in which your father built a cottage from dreams and every day reaped beauty for you and your mother. ${ }^{59}$

The motif of human love in this part of the poem is inseparable from the mystical unity of the spirit - father, mother, daughter, with which marriage is reinterpreted as a mystical motif, and to which Sida Košutić introduces us with the aforementioned spiritual phenomenology of the dialectic between outer and inner space where: "[...] their concordance demands a long process so that they can, with the great-

\footnotetext{
${ }^{56}$ Košutić, "Ime tvoje sveti se," 12.

${ }^{57}$ Gaston Bachelard, Poetika prostora (Zagreb: Ceres, 2000), 27.

${ }^{58}$ Davy, "Predgovor," 8.

${ }^{59}$ Košutić, "Ime tvoje sveti se," 12.
} 
est certainty, determine the points in which they will meet and where they will contradict one another [...]" ${ }^{\prime 60}$. According to Gaston Bachelard, "all is the result of separation and parting: entrance, then exit, nothing is firm, and it may seem that the very centre is wandering, so the individual is indecisively floating, without understanding that it has become the prey of a tiresome asymmetry [...]"61. Here the earthly and the supernatural repeat the dialectic of the internal and the external ${ }^{62}$. And yet, the external and the internal present problems in metaphysical anthropology that are not symmetrical ${ }^{63}$.

A cottage made of dreams, placed in a harvest flower bed, is a symbol of mystical betrothal from which the unborn daughter comes, but is also a powerful signal of the lyric subject's entirely human yearning:

Twin of the stars, storms and the smell of frankincense, only sometimes descended to the earth as an uninvited guest and as its foreigner.

One day, when it descended thus, it brought you and resided with you in the cottage of dreams. ${ }^{64}$

The motif of the "cottage of dreams" corresponds with such a construed mystical space of the supernatural, of destroyed and broken boundaries, just as the selfhood of the poetic subject is construed here: with this Sida Košutić transcends dualistic cognitive concepts (interiority-exteriority, earthly-supernatural, cause-effect, starting pointgoal). She also transcends linguistic dualism further in the poem, where the poetic subject makes the amorous relationship with the man - the father of the "unborn daughter" its theme, by the use of cosmic metaphors. Synaesthesia here gives greater potency to the impact of transcendence by shifting the boundaries of sensory experience. Here the utterance, up to this point a woman's confessional voice in the first person, briefly passes into the third person. The third person usually signifies moving away from "oneself," yet here it still maintains its confessional tone and the primary function of the entire utterance (speech on "selfhood"), by introducing the previously hinted motif of the physical love between a man and a woman. Confession in the third person enacts a strategy of

\footnotetext{
${ }^{60}$ Davy, "Predgovor," 8.

${ }^{61}$ Cit. in: Davy, "Predgovor," 8-9.

${ }^{62}$ Bachelard, Poetika prostora, 210.

${ }^{63}$ Bachelard, Poetika prostora, 212.

${ }^{64}$ Košutić, "Ime tvoje sveti se," 12-13.
} 
elusion in the utterance of the referent, hinted in the symbol of feeding (which corresponds with the symbol of drinking at the beginning of the poem):

One evening before your window

a bashful woman stopped.

He looked into her eyes and led her into the house.

That same night father found your mother.

And never again did anyone overstep the threshold of our

home.

Souls fed from solar plates, that

rang the sacramental song of love. ${ }^{65}$

In the last part of the poem we find again the poetic subject addressing the unborn daughter, a return of motifs of the unattainable, the inability to create the most beautiful poems, as well as a repetition of the motif of the daughter as icon, the closed room, and a closing with a prayer formula. The mystical unity of three persons has been enacted by the use of pronouns, and here the possessive pronoun "njegov" (meaning "his" in English) receives an open meaning, and the referent that it replaces is unclear - the "father of the unborn daughter" or the "flowers" in the previous verse: this is representative of a linguistic strategy of elusion:

In my room there is no longer the odour of flowers, ever since I have absorbed you as I did his odour.

In my room your figure is awaiting me, before whom

my heart is burning like a sacred cresset

My heart be hallowed in your name.

Amen. ${ }^{66}$

A procedure has been enacted in this poem that we can also connect to the strategy of the utterance of a mystical union as the aforementioned point of convergence of existence and transcendence in the mystical union (unio mystica), yet not with the assistance of typical symbols of mysticism such as light, fire etc., but in the unity of the lyric subject and the "unborn daughter," which, on certain occasions, will be provided

\footnotetext{
${ }^{65}$ Košutić, "Ime tvoje sveti se," $12-13$.

${ }^{66}$ Košutić, "Ime tvoje sveti se," 14.
} 
with the form of figurative procedures typical of the biblical. For example, with a repeated chiasm and antimetabole, with the substitution of the function in sentences of the fundamental nouns in the paraphrase of the cited utterance of the Lord's Prayer:

Your name is hallowed in my heart.

My heart is hallowed in your name.

My holy daughter, I love you. ${ }^{67}$

We will notice that the proto-text has received semantic weight according to the discourse of woman's writing: mother addresses daughter, and not, as in the Lord's Prayer, son addressing father, which is provided with potency in the verses where the "daughter" and the Soul are represented as one, just as Jesus and God the Father. This is shown by the procedure of citation and the aforementioned chiasm in the poem's syntax, which alludes to Jesus's High Priestly Prayer in the Gospel according to John, yet also recalls panentheism ${ }^{68}$ :

You are the calm cry of yearning which has run through my blood and imprisoned you in me, me in you. ${ }^{69}$

The unborn daughter, the Soul and the confessional lyric subject here act as one. The subject of utterance constantly slips in this act of equation, and the borders between them are entirely destroyed, the utterance of the object (unborn daughter) is transformed into an utterance on the subject (Soul):

\footnotetext{
${ }^{67}$ Košutić, "Ime tvoje sveti se," 9.

${ }^{68}$ Panentheism and pantheism are two different things, as the first term means that all is in God, while the second term means God is all. M. Eckhart is representative of panentheism as is seen in the following "God created all things in such a way that they are not outside him as the ignorants think" (cit. in: Marijan Jurčević, "Kršćanski pan-en-teizam - mistika stvorenja." In Odgovornost za život (zbornik radova). Eds. B. Vuleta, A. Vučković, (Split: Franjevački institut za kulturu mira, 2000), 298.)

${ }^{69}$ Košutić, "Ime tvoje sveti se," 9.

In the High Priestly Prayer Jesus calls God the Father Abba, praying that his disciples, as all those who will later become his disciples, be One with the Father, just as $\mathrm{He}$ is.

"And all mine are thine, and thine are mine; and I am glorified in them. [...] That they all may be one; as thou, Father, art in me, and I in thee, that they also may be one in us [...]" (The Gospel According To John 17, 10-21, The Holy Bible, Authorized King James Version (Michigan: Zondervan Publishing House, Grand Rapids, 1962), 608.
} 
Saved from death, you remained sublime and worthy to be called Soul. ${ }^{70}$

In the paradox of the 'unborn', the sacred and life eternal are preserved. The auto-referential procedure of the theme of a poet's act of creation is added to the elements of the mystical discourse, informing the utterance on the inability of uttering oneself, with the use of paradox and symbol, which suggest the unsayability of the subject, but with which linguistic and cognitive dualism are transcended through the destruction of the aforementioned dichotomies:

Do you not know, Soul, that your cradle is in the endless spaces of my heart and that I also succeed in lulling you asleep when I sing the most beautiful song?

Do you know, do you know, that the most beautiful song sprouts above your cradle?

This is why it will never be finished, and you will, awake, await me eternally in the endless spaces of my heart ${ }^{71}$.

What is auto-referential here is also ironic in its stance toward the superficial interpretation of her creation which she encounters in the world, in which the apartness and state of being misunderstood of the lyric subject, but also the critical position which does not refrain from naming the superficial people who speak of her as the "ignorant," which directly corresponds to M. Eckhart's text ${ }^{72}$ :

United with me you put a child's words into my mouth.

And the ignorant then consider me childish.

You sometimes glimpse with your harmless soul through my eye.

And the ignorant say, I am pretending.

Through blood you force your way into the colour of my voice.

And the ignorant are fooling themselves, that I am speaking softly warmly. ${ }^{73}$

\footnotetext{
${ }^{70}$ Košutić, "Ime tvoje sveti se," 10.

${ }^{71}$ Košutić, "Ime tvoje sveti se," 11.

72 Compare footnote 68.

${ }^{73}$ Košutić, "Ime tvoje sveti se," 11-12.
} 
And yet it is important to mention that the lyric subject's manifold, and not exclusively spiritual yearning is inscribed into the motif of the "unborn daughter":

I should not have plucked you like a flower, yet I have absorbed you as I absorbed its odour.

I should not have granted you youth, so that you never separate yourself from me. ${ }^{74}$

We should also add the poetic importance of oxymoronic thought in the mystical discourse which is not the reflection of a romantic "portrayal" of the contradictions of man himself, but is closer to a postmodern function in which it "becomes the basis of poetic hermetism," as Krešimir Bagić noted when defining oxymoron ${ }^{75}$.

\section{Conclusion}

The emphatic themes within the construction of the selfhood of the lyric subject in this text, which is enacted by the confessional tone of a female voice, are yearning, poetry, loneliness and a sense of being misunderstood by the community. The verses ("Srce moje sveti se u imenu tvome" / "Ime tvoje sveti se u srcu mome" / "My heart is hallowed in your name" / "Your name is hallowed in my heart") stand in the relationship of a dialogue with the Lord's Prayer. It is obvious that the endeavour of the female lyric subject is that selfhood, uttered in a confessional voice and with auto-referential procedures, which inform the experience of being a poet in a world which misunderstands and misinterprets it (which confirms the subject's critical position), is merged on the textual level with the experience of God's presence, so that the evangelical "father-son-hood" is reinterpreted as "motherdaughter-hood," although there is not a single instance when this lyric subject will address God directly, exclusively addressing the "unborn daughter" or "Soul."

God's presence in the poem is of an exclusively intertextual nature - through allusion by citation, scriptural metaphors and the inheritance of stylistic procedures found in the Bible - antimetabole, chiasm, and prayer formulas, which is the inheritance of Christian mysticism and its

74 Košutić, "Ime tvoje sveti se," 11.

${ }^{75}$ Krešimir Bagić, Rječnik stilskih figura (Zagreb: Školska knjiga, 2012), 209. 
experience of God who is the Word, and which can be interpreted as a textual strategy of the enactment of the idea of God's immanence in human experience: i.e. the concept of panentheism, thus "[...] when there is a deepening $[\ldots]$ of a panentheistic consciousness, we have less need to mention God's name" ${ }^{\text {" }}$. The poem itself, i.e. the act of its origin, represents a moment of the mystical union of all levels of the selfhood (confessional voice, unborn daughter, Soul, existence and transcendence) and here its formulaic closing in prayer fortifies the performativity of this creative, and, also, mystical act. The construct of the lyric subject in the mystical discourse is simultaneously one that conceals and reveals, enacted by the transcending of cognitive and linguistic dualism and referentialism. Yet despite the motifs and the procedures which are indicative of Christian mysticism, the clear poetic reimagining of this discourse in the direction of an utterance of personal preoccupation and content is present in the poem: the yearning of a female subject, poetry, loneliness and being misunderstood by the world at large. Meanwhile, what should also remain in focus is that the panentheistic spirituality here uses the terminology of motherhood when speaking of God, that M. Eckhart speaks of God as the father and the mother at the same time ${ }^{77}$, so that the entire poem can also be interpreted as a mystical relationship between fatherhood and motherhood within God himself which the poet has experienced. It is thus that this $\mathrm{X}$, as a referent which is constantly slipping, which is also the primary characteristic of the mystical (apophatic) discourse, in fact can be related to a spiritual experience, and also that the lyric voice in the first person can suggest an individual addressing God (God the Mother) to a subject which is itself represented as an "unborn daughter" and "Soul," for, as we have seen, there is no real separation between lyric subject and object in this poem, and a being is only ever born in eternity. And yet, it is obvious that this poem does not exclusively make the yearning for spiritual experience its theme, but also the yearning for another human being, as is confirmed by other texts in Sida Košutić's volume of poems.

The question of the unsayable generally, and in poetry specifically, is directly related to the claim that "the duality between reality and representation, radically comprehended as difference, precludes every agreement, convergence and comparison" ${ }^{17}$. In this case, the unsayable remains false, unimportant and peripheral. The analysis of Sida Košutić's text, by using the postmodern model of language which gives

\footnotetext{
${ }^{76}$ Jurčević, "Kršćanski pan-en-teizam - mistika stvorenja," 300.

77 Jurčević, "Kršćanski pan-en-teizam - mistika stvorenja," 300.

${ }^{78}$ Sorić, "Semantički holizam i dekonstrukcija referencijalnosti," 288.
} 
precedence to symbols (language) over the elementary relationships of atomic reference ${ }^{79}$, has shown that every reference, thus, every connection or relation between symbol and object, depends on an entire web of meanings, and not exclusively on a singular reference (and thus either on the reference propounded by the dominant discourse). Sida Košutić's poetic utterance displays an overcoming of semantic atomism (e.g. the unsayable is related to various experiences, states and realities), as well as an overcoming of referentialism and reductionism through the very use of the linguistic practices habitual to mystical discourse (functionally utilised paradoxes, oxymorons, characteristics of biblical style, scriptural metaphors, the experience of mystical union), and thus enacting the position of the critical subject with a foundation in Christian mysticism, even with a panentheistic marker. In the text analysed here, this critical position was primarily related to the theme of being a poet in the world, thus an act of auto-reflection on one's sense of being misunderstood and isolated, ultimately meaning being positioned on the periphery.

\section{References}

Bachelard, Gaston. Poetika prostora. Zagreb: Ceres, 2000.

Bagić, Krešimir. Rječnik stilskih figura. Zagreb: Školska knjiga, 2012.

Biti, Vladimir. Pojmovnik suvremene književne teorije. Zagreb: Matica hrvatska, 1997.

Blakney, Raymond B. Meister Eckhart, A Modern Translation. New York, Hagerstown, San Francisco, London: Harper Torchbooks, 1941.

Davy, Marie-Madeleine. "Predgovor." Preface to Enciklopedija mistika, 1. sv., edited by Madeleine Davy, 6-29. Zagreb: Naprijed, 1990.

Derrida, Jacques. "How to avoid speaking: denials." In Languages of the unsayable. The play of negativity in literature and literary theory, edited by Sandford Budick, Wolfgang Iser, 3-70. Stanford: Stanford University Press, 1996.

Detoni Dujmić, Dunja. Ljepša polovica književnosti. Zagreb: Matica hrvatska, 1998.

Dujić, Lidija. “Ženska signatura. U povodu stote godišnjice rođenja Side Košutić." Vijenac, no. 229 (2002). Accesed October 13, 2019. http://www.matica.hr/ vijenac/229/zenska-signatura-13332/.

Gašpar, Veronika Nela. "Teološko poimanje mučeništva." In Mučeništvo i mučenički tragovi kroz hrvatsku prošlost. Zbornik radova s međunarodnom znanstvenog skupa održanog u Zagrebu 13. ožujka 2014. godine, edited by Mile Bogović, 43-62. Zagreb: Glas Koncila, 2015.

\footnotetext{
${ }^{79}$ Compare: Sorić, "Semantički holizam i dekonstrukcija referencijalnosti," 290.
} 
Ježić, Slavko. Hrvatska književnost (reprint of the first edition of A. Velzek Publishing Office from 1944). Zagreb: Grafički zavod Hrvatske, 1993.

Jurčević, Marijan. “Kršćanski pan-en-teizam - mistika stvorenja.” In Odgovornost za život (zbornik radova), edited by Božo Vuleta and Ante Vučković, 297-312. Split: Franjevački institut za kulturu mira, 2000.

Košutić, Sida, "O umjetnosti (prigodom ankete o katol. književnosti)." Hrvatska prosvjeta, vol. 22, no. 10 (1935): 281-282.

Košutić, Sida. Vjerenička žetva. Zagreb: Hrvatski izdavalački bibliografski zavod, 1942.

Kravar, Zoran. Svjetonazorski separei: antimodernističke tendencije u hrvatskoj književnosti ranoga 20. stoljeća. Zagreb: Golden marketing - Tehnička knjiga, 2005.

Kuvač-Levačić, Kornelija. "Intertekstualnost drame $K$ svitanju Side Košutić i Pjesma nad pjesmama kao prototekst." Crkva u svijetu, vol. 54, no. 1 (2019): $17-41$.

Lice, Stjepan. "Sida Košutić: književnost svjetlosti." Kroatologija, vol. 6, no. 1-2 (2015): 322-341.

Lončarević, Vladimir. Književnost i hrvatski katolički pokret (1900.-1945.). Zagreb: Alfa, 2005.

Maraković, Ljubomir. Novi pripovjedači, kritičke studije i minijature. Zagreb: Hrvatsko društvo sv. Jeronima, 1929.

Milanja, Cvjetko. Hrvatsko pjesništvo 1900.-1950. Novosimbolizam. Dijalektalno pjesništvo, Zagreb: Jerkić tiskara, 2008.

Milanja, Cvjetko. Hrvatsko pjesništvo 1930.-1950. Novostvarnosna stilska paradigma. Zagreb: Matica hrvatska, 2017.

Missatkine, Serge. "Mistika Novoga zavjeta." In Enciklopedija mistika, 1. sv., edited by Madeleine Davy, 183-198. Zagreb: Naprijed, 1990.

Pavličić, Pavao. "Hrvatska lirika tridesetih godina: tipološki opis.” In Komparativna povijest hrvatske književnosti - Zbornik radova VII. (Hrvatska književnost tridesetih godina dvadesetog stoljeća), edited by Cvijeta Pavlović and Vinka Glunčić-Bužančić, 31-47. Split: Književni krug, 2005.

Periša, Ante. Neizrecivo kod Jaspersa i Wittgensteina. Zadar: Hegelovo društvo, 2010.

Petrač, Božidar. "Pogovor.” Foreword to: Košutić, Sida. Različaka čaša. Izabrane pjesme, 154-163. Zagreb: Hrvatska sveučilišna naklada, 1997.

Petrač, Božidar. "Mistički hermetizam Side Košutić (1902.-1965.). Uz 50. obljetnicu pjesnikinjine smrti." Zadarska smotra, vol. 64, no. 3 (2015): 35-39.

Sells, Michael A. Mystical languages of unsaying. Chicago: The University of Chicago Press, 1994.

Sorić, Matko. "Semantički holizam i dekonstrukcija referencijalnosti: Derrida u analitičkom kontekstu." Prolegomena : Časopis za filozofiju, vol. 10, no. 2 (2011): 281-309. Accessed October 13, 2019, https://hrcak.srce.hr/74467.

Šicel, Miroslav. Povijest hrvatske književnosti XX. stoljeća. Razdoblje sintetičkog realizma : (1928-1941), knj. 5. Zagreb: Naklada Ljevak, 2009.

Šimunić-Kesterčanek, Nada. "Sida Košutić kao umjetnica." Preface to: Košutić, Sida. Mimoza sa smetljišta (novele), 7-26. Zagreb: Be-1-ka, 1942. 
Špehar, Milan. "Mistika u životu kršćana." Bogoslovska smotra, vol. 75, no. 1 (2004): 87-123. Accessed October 7, 2019, https://hrcak.srce.hr/25648.

The Holy Bible, Authorized King James Version. Michigan: Zondervan Publishing House, Grand Rapids, 1962.

Vörös, Sebastjan. "Mahakashyapa's Smile: Language, Silence, and Mysticism." Synthesis Philosophica, vol. 29, no. 2 (2014): 387-402. Accessed October 18, 2019, https://hrcak.srce.hr/142433.

“Ženski sat na krugovalu” (unsigned). Hrvatski ženski list, no. 7-8 (1943): 23.

\section{Kršćanski misticizam Side Košutić - na periferiji kanona nacionalne književnosti}

Sažetak: Istraživanjem će se prikazati nekoliko ključnih uzroka recepcijske i književnopovijesne perifernosti bogata literarnog opusa hrvatske pjesnikinje, esejistice, pripovjedačice i autorice jedne drame Side Košutić. Dok većina dosadašnjih istraživanja s pravom navodi ideološke i svjetonazorske uzroke rubnog položaja Side Košutić u kanonu nacionalne književnosti, ovdje će se dominantno istraživati književničin iskaz o neizrecivome u ključu kršćanskoga mističnoga iskustva. Time se ovo istraživanje uklapa u suvremeni interesfilozofije jezika i književne teorije za problematiku izricanja neizrecivoga (L. Wittgenstein, K. Jaspers, J. Derrida, M. Sells i dr.). Istaknuti će se elementi mističnoga diskursau književničinom lirskom iskazu analizirati na primjeru pjesme ("Ime tvoje sveti se") koja donosi glavninu poetičkih postupaka iz čitave zbirke Vjerenička žetva. Mistički je hermetizam također jedan od mogućih uzroka perifernosti književničina djela, no ukoliko se u interpretaciju uključi postavke postmodernističkoga modela jezika, dolazi se do zaključka da iskaz književnice nadilazi semantički atomizam (neizrecivo se odnosi na različita iskustva, stanja i stvarnosti), reprezentacionalizam i referencijalizam jezičnih praksa. Kritički subjekt Side Košutić pronalazi svoje legitimacijsko uporište u kršćanskom misticizmu. Analiza postupaka dovodi do zaključka da se njezino djelo može ravnopravno uključiti u poetičke smjernice hrvatske moderne književnosti prve polovice 20. stoljeća narušavajući pritom dominantne predodžbe o središtu i periferiji koje je definirao nacionalni književni kanon.

Ključne riječi: Sida Košutić, kršćanski misticizam, neizrecivo, periferija, hrvatska moderna književnost 